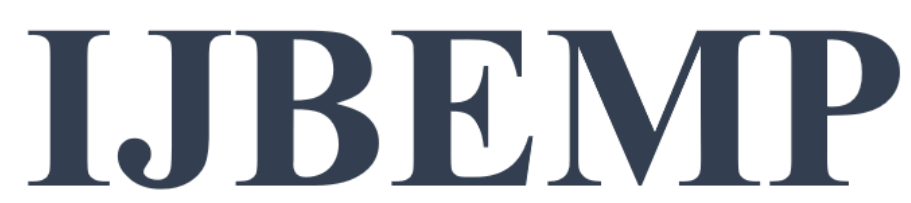

\title{
INDICATORS OF PREFERENCE FOR PARTICIPATION BANKING: A RESEARCH ON PEOPLE WHO DO NOT USE PARTICIPATION BANKING IN THEIR FINANCIAL TRANSACTIONS
}

\section{Gökhan ÖZKUL}

Assist. Prof. Dr., Süleyman Demirel University, Faculty of Economics and Administrative Sciences, Department of Finance and Banking, gokhanozkul@sdu.edu.tr, https://orcid.org/0000-0001-7545-8292

\section{Özgenur ÇAKIR}

Süleyman Demirel University, Graduate School of Social Sciences, Department of Finance and Banking, ozgenurcakir50@gmail.com, https://orcid.org/0000-0002-8185-1872 


\title{
INDICATORS OF PREFERENCE FOR PARTICIPATION BANKING: A RESEARCH ON PEOPLE WHO DO NOT USE PARTICIPATION BANKING IN THEIR FINANCIAL TRANSACTIONS
}

\begin{abstract}
Participation banking having an increasing cut in finance market more and more is a banking model, which enables people who have a sensibility of interest, to participate the system by preventing the sources from being idle. These banks aim to realize all banking activities in terms of interest free principles. In recent years, there has been an increasing attention to these banks since a great number of people try to avoid interest income because of religious purposes in both Turkey and the world. Especially, the increase in the number of participation banks in Turkey has created a potential of being an alternative to conventional banks. In the meantime, there are various factors affecting the preference for using participation banks in financial transactions. Concordantly, the aim of this study is to investigate what affects potential customers who do not use participation banking in their financial transactions in future by using factor analysis. Within this scope, a research has been carried out on academicians in Faculty of Economics and Administrative Sciences of Süleyman Demirel University by using questionnaire method. The factors affecting the academicians who do not use participation banks to decide to use it in future has been prioritized as product/service range and quality, financial inclusion, religion, trust and social environment according to the factor analysis result done in the light of obtained information.
\end{abstract}

Keywords: Islamic Banking, Participation Banking, Preference for Participation Banking, Factor Analysis.

JEL Classification Codes: G20, G21, G29.

\section{KATILIM BANKACILIĞI TERCIHININ BELIRLEYICILERİ: FİNANSAL IŞLEMLERINDE KATILIM BANKALARINI KULLANMAYANLAR ÜZERINNE BİR INCELEME}

ÖZ

Finans piyasalarındaki payı gün geçtikçe artış gösteren katılım bankacılı̆̆ı, faiz hassasiyeti duyan bireylerin, ekonomik sisteme entegre olmasını sağlayarak kaynakların atıl durmasını engelleyen bir bankacılık modelidir. Bu bankalar faizsizlik prensiplerine göre her türlü bankacılık faaliyetlerini gerçekleştirmeyi amaçlamaktadır. Türkiye'de ve dünyada dini gerekçelerle faiz gelirinden uzak durmaya çalışan küçümsenmeyecek sayıda kesimin bulunması son yıllarda bu bankalara olan ilginin artmasına neden olmuştur. Özellikle Türkiye'de katılım bankaları sayısında meydana gelen artış, bu bankaların konvansiyonel bankalara alternatif olma durumunu yaratmıştır. Bununla birlikte finansal işlemlerde katılım bankalarını kullanma tercihini etkileyen çeşitli faktörler vardır. Bu bağlamda çalışmanın amacı finansal işlemlerinde katılım bankalarını kullanmayan potansiyel müşterilerin gelecekte katılım bankacılığını kullanma kararını vermelerinde nelerin etkili olabileceğini faktör analiziyle incelemektir. Bu çerçevede çalışmada anket yöntemi kullanılarak Süleyman Demirel Üniversitesi İktisadi ve İdari Bilimler Fakültesi'nde çalışan akademisyenler üzerinde bir araştırma yapılmıştır. Elde edilen veriler ışığında yapılan faktör analizi sonuçlarına göre ise katılım bankalarını kullanmayan akademisyenlerin gelecekte katılım bankaları ile çalışma kararını vermede etkili olan faktörlerin önem sırasına göre ürün/hizmet çeşitliliği ve kalitesi, finansal erişim, din ve güven ile sosyal çevre olduğu bulunmuştur.

Anahtar Kelimeler: İslami Bankacılık, Katılım Bankacılı̆̆ı, Katılım Bankacılığı Tercihi, Faktör Analizi.

JEL Sinıflandırma Kodları: G20, G21, G29. 


\section{INTRODUCTION}

Participation banking, also called Islamic or interest free banking, gained ground as a banking model having an increasing importance in not only Muslim countries but also other countries in the world (Pehlivan, 2016: 296; Atici, 2018: 1355). Its structure turning from an institution allocating micro credits into a systematic model has a significant role in this situation (Atici, 2018: 1355). Participation banking is a banking model performing profit and loss sharing in terms of interest free principles. It has a process enabling application of funds with trade, partnership and leasing methods by collecting funds based on the principal of profit and loss sharing. The word "participate" is used to express that it is a banking model based on participating in the profit and loss. Therefore, these banks use collected funds in trade and industry in terms of interest free principle and share the obtained profit and loss with fund holders (TKBB, 2020a: 2). While debtor takes all the risks in conventional banking system, they have been shared between fund holder and investor in participation banking system.

Participation and conventional banks are both financial institutions collecting funds, using these funds and serving other banking activities. The main difference of participation banks is to serve these three services depending on the interest free principles. Therefore, the main difference of participation banking from conventional banking is to make interest free transactions. Interest can be described as the income obtained from forward sale. The income obtained from transactions on money will be the interest. In participation banking, transactions are not implemented on money but a system has been applied based on the profit share principle. In this system, the profit share is determined at the end of the expiry date, and they are paid from the profit obtained as a result of using collected funds. The profit which banks have obtained as a result of using collected funds is parallel with the profit share that is paid to the fund holder. So, the more banks make profit the more fund holder makes. The decrease in profit that banks make causes a decrease in fund holder's profit (TKBB, 2020a: 7-9; Day1, 2019: 1789). On the other hand, conventional banking is a model collecting and sharing funds with interest (Kalayc1, 2013: 52-53).

The main purpose in conventional banking is to reach the maximum profit within the limits of the law without considering how the money is obtained. Thus, these banks can take part in any activities that make profit. As for participation banking, it focuses not only the profit but also its availability to Islamic principles (Demirdöğen and Özkul, 2018: 340). In this respect, participation banking serves a more humanistic financial model and aims a system connecting the economy to people not people to economy (Hazıroğlu, 2019: 31-32).

Participation banking has been a growing banking model in recent years since it has the potential of bringing fund holders who do not prefer interest into the economic system (Yanik and Sumer, 2017: 430). Its cut has been increasing in Turkish banking sector. In Turkish banking sector, 53 banks were in service at end of the year 2019 and 6 of them were participation banks (TKBB, 2020b: 45). Participation banks have constituted more than $10 \%$ of the banking sector with 1179 domestic and abroad branches. Total numbers of employees have been 16.040 at the end of the year 2019 by increasing $2.5 \%$ in comparison with 2018. Rapid improvements in financial technologies have affected the numbers of customers of participation banks and the numbers of online banking customers have increased 3.620.387 in 2019 by increasing 141\% in comparison with the previous year. Non-consolidated total assets of participation banks in Turkey have reached 284,459 million Turkish Liras by increasing 37.5\% in 2019 in comparison with 2018. Consequently, participation banks whose aim is to serve all banking products and services in terms of interest free principles have been growing fast in Turkey and have been increasing the numbers of potential customers with their new services: mudarabah (labor capital partnership), usury (financial trade), musharakah (profit/loss participation), istisna' (agreement for work), salam (advance payment, charge sale), qard hasan (interest free loan), takaful (Islamic insurance system), participation indexes and exchange traded funds based on the participation indexes, interest free PPS (private pension system), sukuk (lease certificate), investment procuration, etc. (TKBB, 2020b: 57-61).

It can be said that the attention to participation banking also called Islamic banking are in tendency to increase all over the world when it is thought that Islamic financial assets rising in 1970s has reached 2,5 trillion USD by increasing 3\% (IFDI, 2019: 6). Participation banking has been 
maintaining its improvement both in Turkey and in the world as a new banking model having a great growth potential. The aim of this study is to search effective factors in deciding to use participation banking in financial transactions in future with factor analysis. In this context, a research has been carried out on academicians in Faculty of Economics and Administrative Sciences of Süleyman Demirel University by using questionnaire method in order to reveal people's point of view for participation banking system. Academicians' attitudes towards participation banking have been examined and factors affecting to increase the customer potential of participation banks have been revealed. First of all, the indicatives of preferences for participation banking in Turkey have been discussed. Later, the research methodology has been mentioned. Then, research findings have been presented and the study will be ended up with a conclusion part.

\section{INDICATORS OF PREFENRENCES FOR PARTICIPATION BANKING IN TURKEY}

Developments in the financial markets, globalization and monetary expansion based on petrol have forced Islamic countries to set an acceptable financial system which is suitable for their values and beliefs. Along with the founding the Islamic Development Bank in 1975, Islamic banking system has been discussed as an alternative to conventional banking in Islamic world. It has been seen that similar discussions have been observed after 1980s in Turkey. Using "participation banks" term with the legal regulations in 2005 has added a new dimension to the interest for participation banking in Turkey. Especially the government banks stepping into the participation banking sector have caused an increase in confidence and attention for the sector (Demirdöğen and Özkul, 2018: 344-345, Demirdöğen and Kaplan, 2020; 40). These improvements have an effect on academic researches about participation banking and the number of studies carried out for the development of participation banking sector have begun to increase in academic community. It has seen that a great majority of the studies have focused the reasons for preferring the participation banking emerging as an alternative to conventional banking. It can be said that most of the studies are at regional level. Within this scope, these are some of the outstanding empirical studies:

Özsoy et al. (2013) have investigated the reasons for preferring the participation banking in Bolu by using the exploratory factor analysis technique. In the study, the data have been obtained from 217 customers in three participation banks in Bolu by using the questionnaire method. It has been presented that the factors affecting the preference of participation bank are product/service quality, image and trust, personal quality and religious/environmental motivation factors.

Ergeç et al. (2014) have an investigation on 500 participation bank customers in Eskişehir by using questionnaire method with the aim of determining their attitudes towards conventional banks when they present Islamic banking's products and services. It has been presented in the study using descriptive analyses and chi square test that participation bank customers have supported the conventional banks in serving the Islamic banking products and services. It has been indicated that there is a statistically significant relation between the participation bank customers' and conventional banks' attitudes towards Islamic banking and customers' job status, education level, working history with participation banks, gratitude for participation banks and participation bank they work with.

Gençtürk and Çobankaya (2015) have targeted to reveal the reasons why people are not using participation banks and will not use them in future with the aim of determining their feelings related to participation banks in western Mediterranean region. The questionnaire method has been preferred as data collection method. In the light of the data obtained from 470 people, it has been seen that 183 people are not using participation banking and will not use it in future. $34,7 \%$ of them think that participation banks are not different from the other banks, $31,7 \%$ of them don't find the participation banks reliable, $15,3 \%$ of them find their services insufficient and $11,7 \%$ of them don't prefer participation banks because they can't obtain interest income.

Toraman et al. (2015) have investigated current and potential customers' attitudes towards participation banking activities in Gaziantep by using questionnaire method. The questionnaire data obtained from 539 people have been analyzed with the help of frequency analysis and anova test. It has been presented that there are three main differences- the knowledge level of participation banking and its accessibility, advertising the banking products and services and the frequency of commercials and the religious concerns in preferring the Islamıc banking - between the potential customers who consider 
working with a participation bank and the customers who are negative and indecisive about Islamic bank. In the study, it has been stated that the potential customers who are indecisive and do not consider working with a participation bank have less information about Islamic banks, think that there are less advertisements about it and less accessible in comparison with the others.

Anaç and Kaya (2017) have investigated the reasons for preferring participation bank in four participation banks in Istanbul by using factor analysis technique. As a result of the analysis of the questionnaire data obtained from 423 people, it has been stated that the most important factor in preferring the participation banks is their popularity and image as an interest free institution. In the study, this factor has been followed by the factors of directing the religious sensibility and workers' approaches towards the customers.

Demirdöğen and Özkul (2018) have investigated the factors affecting the preference of using participation banking in banking transactions in the light of questionnaire data obtained from 400 people by using statistical analyses, independent samples t-test and one way anova test. In the study, only $28,2 \%$ of the participants have been using the participation bank. It has been stated that the religious sensibility as the most important factor has been followed by the factors of service quality and ease of transactions. It has been determined in the study that there are statistically meaningful differences between consumers' job statements, their emphasis on religious concerns, their knowledge of Islamic finance and the difference from conventional banks and their preference of participation banks.

Öndeş et al. (2018) have investigated the reasons why customers using credit from banks do not prefer the participation banks in Erzurum by using questionnaire method. In the study, the data obtained from 228 academicians working in Atatürk University has been analyzed with the help of descriptive statistics and the chi square test. As a result of the research, high financing cost, inadequate product diversity, necessity of direct financing, insufficient number of branches and ATMs have been presented as the reasons why participation banks are not preferred.

Turan and Demirci (2019) have examined the attitudes of the academicians working in a state university towards using interest and interest free finance by using questionnaire method. In the study, it has been revealed in the light of data obtained from 51 academicians that the rate of the academicians having positive attitude towards participation banks is $18 \%$. Insufficient information about participation banks and having almost no difference from conventional banks have affected the academicians' perceptions negatively.

Çambel (2019) has investigated the factors affecting the businesses' preference for participation banks in the study carried out on 225 businesses operating in Bolu. In the study, the factors affecting their tendency of using participation banks have been mentioned and the relation between the demographic qualifications of employers or partners and the reasons why they prefer participation banks have been tried to be explained. In consequence of the research, interest free principle, Islamic concerns and close relations with the bank workers have been stated as the most outstanding factors affecting the preference for participation banking.

Yanık and Sumer (2019) have aimed to investigate the 43 academicians' perceptions of participation banking in departments of religious faculty of Atatürk University by using the data obtained by questionnaire method. As a result of the study, it has been observed that the academicians do not have sufficient information about the participation banking.

Erdoğan et al. (2020) have examined the reasons why people prefer participation banks in Kocaeli by using questionnaire method. According to the factor analysis carried out in the light of the data obtained from the questionnaire conducted on 407 participation bank customers, it has been revealed that five fundamental factors - religious concerns, variables related to service quality, the effect of social environment, financial variables and marketing mix - are effective in preferring the participation banks.

As an alternative to these studies carried out at regional level, there are other studies focusing the indicatives of preferences for participation baking in Turkey. Some of the outstanding studies in literature are herein below: 
Polat et al. (2014) have investigated the factors affecting the preference for participation banking by using confirmatory factor analysis method. According to questionnaire data obtained from 341 participation bank customers, it has been seen that participation banking, high quality banking and fast banking are three determinant factors affecting the customers' preferences for banks.

Y1ldırım and Çakar (2016) have investigated the factors affecting the preference for participation banking with the help of exploratory factor analysis. In the light of the data obtained from questionnaire carried out on 708 academicians throughout Turkey, the effects of religious concerns, service quality, reliability and awareness and transparency have been investigated in terms of preferring participation banking. According to the obtained findings, while the perception of service quality is the most important factor in preferring participation banks, awareness and transparency and reliability are the other important factors. It has been seen that the religious concerns has no effect on the intention of using participation banking.

Törenek and Yavuz (2018) have investigated the effect of demographic qualifications on preference of participation banks by using t-test and one way anova test techniques. Analyses have been carried out in the light of the data obtained from questionnaires done 516 people from five different participation bank customers in 23 cities. Educational background has a meaningful effect on the perception of preferring for participation banks while gender, age, marital status and level of monthly income have almost no effect.

Dayı (2019) has examined the reasons for preferring participation banks, customer loyalty and reliability by using structural equation model. According to the questionnaire data obtained from 406 participation bank customers, the most important reason for preferring participation banks is religious concerns. This reason has been followed by taking no transaction fees. In the study, it has been determined that image, personal quality and the motivation of religious environment have a meaningful effect on reliability. Thus, the reliability has an effect on loyalty and the religious environment and motivation have an effect on loyalty.

When the studies carried out on the indicatives of preference for participation banking have been examined, it has been seen that the questionnaire method has been commonly used in the literature. It can also be said that the studies have been carried out at regional level. The most used techniques are descriptive analyses, $t$ test, anova test, chi-square test, factor analysis and structural equation model. Most of the studies have focused on current participation bank customers. The number of researches focusing the potential customers who are not using participation banking in their financial transactions is poor. It can be said that the number of studies focusing on a significant sector is also low. Therefore, the most fundamental factor making this study different from others is to focus on potential academicians who are not using participation banks.

\section{METHODOLOGY}

The aim of the study is to investigate which factors can be effective in academicians' preference for using participation banking in future who do not use it in their financial transactions by using factor analysis. In this sense, in order to reveal the people's point of views towards participation banking who do not use it, a research has been carried out on academicians in Faculty of Economics and Administrative Sciences of Süleyman Demirel University by using questionnaire method. The reason why academicians in Faculty of Economics and Administrative Sciences have been chosen is that they know the participation banking system better than the other academicians working in other faculties and they can reveal the reasons determining their preferences between conventional banking and participation banking. Thus, providing a basis for further studies which will be done in all units has been aimed.

The questionnaire in the research has been developed by using the studies of Özsoy et al. (2013), Yıldırım and Çakar (2016), Anaç and Kaya (2017) and Gökçen and Gönen (2017). The sample size has been calculated before the questionnaire. The number of academicians working in Faculty of Economics and Administrative Sciences in Süleyman Demirel University on May 2019 is 171 (https://iibf.sdu.edu.tr, 2019). 171 academicians have constituted the basis of the study. The following formula has been used in calculating the sample size because the number of individuals has been known (Salant and Dillman, 1994: 55). 


$$
\mathrm{n}=\frac{\mathrm{N} \cdot \mathrm{t}^{2} \cdot \mathrm{p} \cdot \mathrm{q}}{\mathrm{d}^{2} \cdot(\mathrm{N}-1)+\mathrm{t}^{2} \cdot \mathrm{p} \cdot \mathrm{q}}
$$

$\mathrm{N}$ is the number of individuals targeted, $\mathrm{n}$ is the number of individuals in sample, $\mathrm{p}$ is the frequency of occurrence of the investigated phenomenon, $q$ is the frequency of non-occurrence of the investigated phenomenon, $t$ is the theoretical value obtained according to the $t$ table at a significance level and $\mathrm{d}$ is the accepted sampling error according to the frequency of occurrence of the phenomenon in the formula.

$$
\mathrm{n}=\frac{171 \cdot 1,96^{2} \cdot 0,5 \cdot 0,5}{0,05^{2} \cdot(171-1)+1,96^{2} \cdot 0,5 \cdot 0,5}=\frac{164,2284}{1,3854}=118,5
$$

As it has been seen above, the sample size is approximately 119 for $5 \%$ sampling error in $95 \%$ confidence interval according to the calculation. The questionnaire has been carried out on May 2019 with 119 academicians by using random sampling method has been used as a method. $69,6 \%$ of the population has been reached with 5\% sampling error in 95\% confidence interval. SPSS (Statistical Package for the Social Sciences) program has been used in the analyses of the data obtained after the questionnaire. Descriptive statistical analyses and exploratory factor analysis have been carried out in the research.

\section{FINDINGS OF THE RESEARCH}

First of all, the demographical findings related to the academicians have been investigated in terms of the usage of participation banks.

\begin{tabular}{|c|c|c|c|c|c|c|c|}
\hline & & \multicolumn{6}{|c|}{ The Usage of Participation Banks } \\
\hline & & \multicolumn{2}{|c|}{ Yes } & \multicolumn{2}{|c|}{ No } & \multicolumn{2}{|c|}{ Total } \\
\hline & & $\mathbf{F}$ & $\%$ & $\mathbf{F}$ & $\%$ & $\mathbf{F}$ & $\%$ \\
\hline \multirow{2}{*}{ Gender } & Female & 3 & 6,7 & 42 & 93,3 & 45 & 100 \\
\hline & Male & 13 & 17,6 & 61 & 82,4 & 74 & 100 \\
\hline \multirow{4}{*}{ Age } & 30 and under & 3 & 8,6 & 32 & 91,4 & 35 & 100 \\
\hline & $31-40$ & 9 & 19,1 & 38 & 80,9 & 47 & 100 \\
\hline & 41-50 & 3 & 9,7 & 28 & 90,3 & 31 & 100 \\
\hline & 51 and above & 1 & 16,7 & 5 & 83,3 & 6 & 100 \\
\hline \multirow{2}{*}{ Knowing the Difference of Participation Banks } & Yes & 16 & 17,2 & 77 & 82,8 & 93 & 100 \\
\hline & No & 0 & 0,0 & 26 & 100 & 26 & 100 \\
\hline \multirow{2}{*}{ Marital Statuses } & Married & 15 & 16,1 & 78 & 83,9 & 93 & 100 \\
\hline & \begin{tabular}{|l|} 
Single \\
\end{tabular} & 1 & 3,8 & 25 & 96,2 & 26 & 100 \\
\hline \multirow{3}{*}{ Income (TL) } & 6.000 under & 5 & 8,9 & 51 & 91,1 & 56 & 100 \\
\hline & \begin{tabular}{|l|}
$6.000-9.999$ \\
\end{tabular} & 8 & 16,0 & 42 & 84,0 & 50 & 100 \\
\hline & 10.000 and above & 3 & 23,1 & 10 & 76,9 & 13 & 100 \\
\hline \multirow{4}{*}{ Title } & Prof. Dr. & 3 & 27,3 & 8 & 72,7 & 11 & 100 \\
\hline & Assoc. Prof. Dr. & 0 & 0 & 19 & 100,0 & 19 & 100 \\
\hline & Assist. Prof. Dr. & 7 & 15,9 & 37 & 84,1 & 44 & 100 \\
\hline & Research Assist. / Lecturer & 6 & 13,3 & 39 & 86,7 & 45 & 100 \\
\hline & Total & 16 & 13,4 & 103 & 86,6 & 119 & 100 \\
\hline
\end{tabular}

Table 1. Demographic Findings

As it can be seen in Table 1, while 13,4\% of 119 academicians use participation banks in their financial transactions, $86,6 \%$ of them do not use participation banks. 45 of the respondents are female and 74 of them are male. When it has been examined the usage rate of the participation banks between male and female individuals, $17,6 \%$ of male individuals and $6,7 \%$ of female individuals use participation banks. When the marital statuses of them have been investigated, it has been seen that 78 of them are married and 25 of them are single. The rate of using participation banks for married academicians is higher than single ones with $16,1 \%$. When the age distribution has been examined, 35 of them are 30 and under, 47 of them are between 31 and 40,31 of them between 41 and 50,6 of them are 51 or above. While the highest usage in participation bank is the group with 19,1\% whose ages are between 31 and 40 , the lowest usage is the group with $8,6 \%$ whose ages are 30 or below. When the participants have 
been evaluated in terms of income level, it has been seen that 56 of them earn less than $6000 \mathrm{TL}, 50$ of them earn between 6000 and 9999 TL and 13 of them earn 10000 TL or more. The highest usage in participation banks is the group whose income are $10000 \mathrm{TL}$ or more with $23,1 \%$ while the lowest usage is the group whose income are less than $6000 \mathrm{TL}$. In other words, the number of people using participation banks increases depending on their income levels. When the academicians have been evaluated in terms of their titles, it has been seen that 11 of them are professor doctors, 19 of them are associate professors, 44 of them are assistant professors and 46 of them are research assistants and lecturer. The highest rate of the title groups using participation banks are the professor doctors' one with $27,3 \%$ while the lowest participation rate belongs to assistant doctors. When the participants have been evaluated in terms of the knowledge about the difference between conventional and participation banks, 93 of them have expressed that they know the difference but 26 of them have expressed that they don't. The academicians who do not know the difference between them do not use the participation banks. The percentage of usage between the academicians who know the difference is $17,2 \%$.

After the academicians have been evaluated in terms of their demographic findings, it has been investigated what will be effective in 103 academicians' decisions of using participation banks in future. In table 2, 18 criteria have been determined by using the literature related to factors affecting the decision of preferring participation banks in future. A five point likert type scale (1: Strongly disagree to 5: Strongly agree) has been used to evaluate these criteria for the decision of using participation banks in future.

Table 2. The Factors Affecting the Usage of Participation Banks in Future

\begin{tabular}{|l|l|c|c|c|}
\hline & \multicolumn{1}{|c|}{ Criteria } & N & Mean & Std. Dev. \\
\hline C1 & I work with participation bank if it is a public financed bank (state bank) & 103 & 2,78 & 1,379 \\
\hline C2 & I work with participation bank if it has a good image & 103 & 3,08 & 1,384 \\
\hline C3 & I work with participation bank if it gives importance to religious concerns & 103 & 2,78 & 1,488 \\
\hline C4 & $\begin{array}{l}\text { I work with participation bank if it increases the diversity of products and } \\
\text { services }\end{array}$ & 103 & 3,15 & 1,396 \\
\hline C5 & $\begin{array}{l}\text { I work with participation bank if it makes a satisfying presentation for a product } \\
\text { and a service }\end{array}$ & 103 & 3,10 & 1,383 \\
\hline C6 & $\begin{array}{l}\text { I work with participation bank if it has attractive profit shares and payment } \\
\text { options }\end{array}$ & 103 & 3,13 & 1,446 \\
\hline C7 & I work with participation bank if it offers low cost credit & 103 & 3,36 & 1,392 \\
\hline C8 & I work with participation bank if it doesn't take account maintenance fee & 103 & 3,25 & 1,460 \\
\hline C9 & I work with participation bank if a relative of mine starts working there & 103 & 2,17 & 1,222 \\
\hline C10 & I work with participation bank if one of my friends or relatives proposes it & 103 & 2,40 & 1,346 \\
\hline C11 & I work with participation bank if it provides ease of transaction & 103 & 3,21 & 1,398 \\
\hline C12 & $\begin{array}{l}\text { I work with participation bank if it offers a credit or debit card providing extra } \\
\text { advantages }\end{array}$ & 103 & 3,01 & 1,404 \\
\hline C13 & $\begin{array}{l}\text { I work with participation bank if it provides currency advantages in foreign } \\
\text { exchange purchase and sale transactions in comparison with the market }\end{array}$ & 103 & 3,22 & 1,393 \\
\hline C14 & $\begin{array}{l}\text { I work with participation bank if it offers banking services special to the } \\
\text { customer }\end{array}$ & 103 & 3,21 & 1,398 \\
\hline C15 & I work with participation bank if it has great number of ATMs & 103 & 2,98 & 1,442 \\
\hline C16 & I work with participation bank if it is near my home or workplace & 103 & 2,54 & 1,399 \\
\hline C17 & $\begin{array}{l}\text { I work with participation bank if it has high numbers of branches and } \\
\text { transportation opportunities }\end{array}$ & 103 & 2,88 & 1,437 \\
\hline C18 & I work with participation bank if its internet site and mobile application is useful & 103 & 3,03 & 1,492 \\
\hline
\end{tabular}

When the Table 2 has been examined, it has been seen that the most important factor affecting the decisions of using participation banks in future is "I work with participation bank if it offers low cost credit" criterion with 3,36 average. This criterion has been followed by the criteria of "I work with participation bank it doesn't take account maintenance fee" with 3,25 average, "I work with participation bank if it provides currency advantages in foreign exchange purchase and sale transactions in comparison with the market" with 3,22 average, "I work with participation bank if it provides ease of transaction" and "I work with participation bank if it offers banking services special to the customer" with 3,21 averages. In return for this, the least effective factor in preferring for participation banks in future is "I work with participation bank if a relative of mine starts working there" with 2,17 average. This criterion has been followed by the criteria of "I work with participation bank if one of my friends 
or relatives proposes it" with 2,40 average and "I work with participation bank if it is near my home or workplace" with 2,54 average.

These 18 criteria have been analyzed with exploratory factor analysis in order to reveal the factors affecting the decision of using participation banks in future. Factor analysis is a multivariate statistical method converting a great number of variables into fewer factors which are meaningful and independent from one another. Several methods are a matter of factor analysis. The most widespread one is the principal component analysis (Kalayc1, 2010: 321). Therefore, the principal component analysis has been used in the study. Varimax has been used as factor rotation method.

The data set has needed to be tested in order to carry out factor analysis. A reliability test has been done for 18 criteria. Cronbach's alpha coefficient has been determined as 0,958 . It can be said that the data set provides the required reliability condition for factor analysis because the reliability coefficient is close to 1 .

After the reliability test, Kaiser-meyer-olkin sampling adequacy has been tested by using Barlett test showing if there is an enough relationship between the variables. Since p value of Barlett test (Sig.) is lower than 0,05significance level, there is an enough relationship between variables for factor analysis. Similarly, Kaiser-Meyer-Olkin sampling adequacy scale is above the lowest acceptable value of 0,50 and its suitability for factor analysis is at perfect level. Anti-image correlation matrix has been investigated in order to measure the every issue's suitability for factor analysis. It has been controlled if all correlation values in this matrix are lower than 0,50 or not and determined that all values are above 0,50 .

Table 3. Kaiser-Meyer-Olkin and Bartlett Test

\begin{tabular}{|l|l|r|}
\hline Kaiser-Meyer-Olkin Measure of Sampling Adequacy &, 913 \\
\hline Bartlett's Test of Sphericity & Approx. Chi-Square & 1668,224 \\
\cline { 2 - 3 } & df & 153 \\
\cline { 2 - 3 } & Sig. &, 000 \\
\hline
\end{tabular}

Eigenvalue statistic has been taken as a base in determining the factors. The factors whose eigenvalues are higher than 1 have been accepted as meaningful (Kalayc1, 2010: 322).

Table 4. Total Variance Explained

\begin{tabular}{|c|c|c|c|c|c|c|}
\hline \multirow{2}{*}{ Component } & \multicolumn{3}{|c|}{ Initial Eigenvalues } & \multicolumn{3}{|c|}{ Rotation Sums of Squared Loadings } \\
\hline & Total & \% of Variance & Cumulative \% & Total & $\%$ of Variance & Cumulative \% \\
\hline 1 & 10,610 & 58,944 & 58,944 & 5,547 & 30,818 & 30,818 \\
\hline 2 & 1,441 & 8,004 & 66,948 & 3,736 & 20,756 & 51,574 \\
\hline 3 & 1,051 & 5,838 & 72,786 & 2,920 & 16,225 & 67,799 \\
\hline 4 & 1,034 & 5,743 & 78,530 & 1,931 & 10,730 & 78,530 \\
\hline 5 & ,553 & 3,073 & 81,602 & & & \\
\hline 6 &, 504 & 2,797 & 84,400 & & & \\
\hline 7 & 468 & 2,600 & 87,000 & & & \\
\hline 8 & 420 & 2,334 & 89,334 & & & \\
\hline 9 & ,320 & 1,776 & 91,110 & & & \\
\hline 10 & ,282 & 1,567 & 92,677 & & & \\
\hline 11 & ,264 & 1,466 & 94,144 & & & \\
\hline 12 & ,241 & 1,337 & 95,481 & & & \\
\hline 13 & , 197 & 1,093 & 96,574 & & & \\
\hline 14 &, 180 & ,999 & 97,572 & & & \\
\hline 15 & , 140 &, 776 & 98,348 & & & \\
\hline 16 &, 112 & ,623 & 98,971 & & & \\
\hline 17 & , 104 &, 577 & 99,548 & & & \\
\hline 18 & ,081 & ,452 & 100,000 & & & \\
\hline
\end{tabular}

Extraction Method: Principal Component Analysis

When the table 4 has been examined, there are four factors whose eigenvalues are higher than 1. Factor 1, 2, 3 and 4 have explained $30,818 \%, 20,756 \%, 16,225 \%$ and $10,730 \%$ of the total variance. These four factors generated with the help of 18 criteria have explained $78,530 \%$ of the total variance. 
Table 5. Rotated Component Matrix

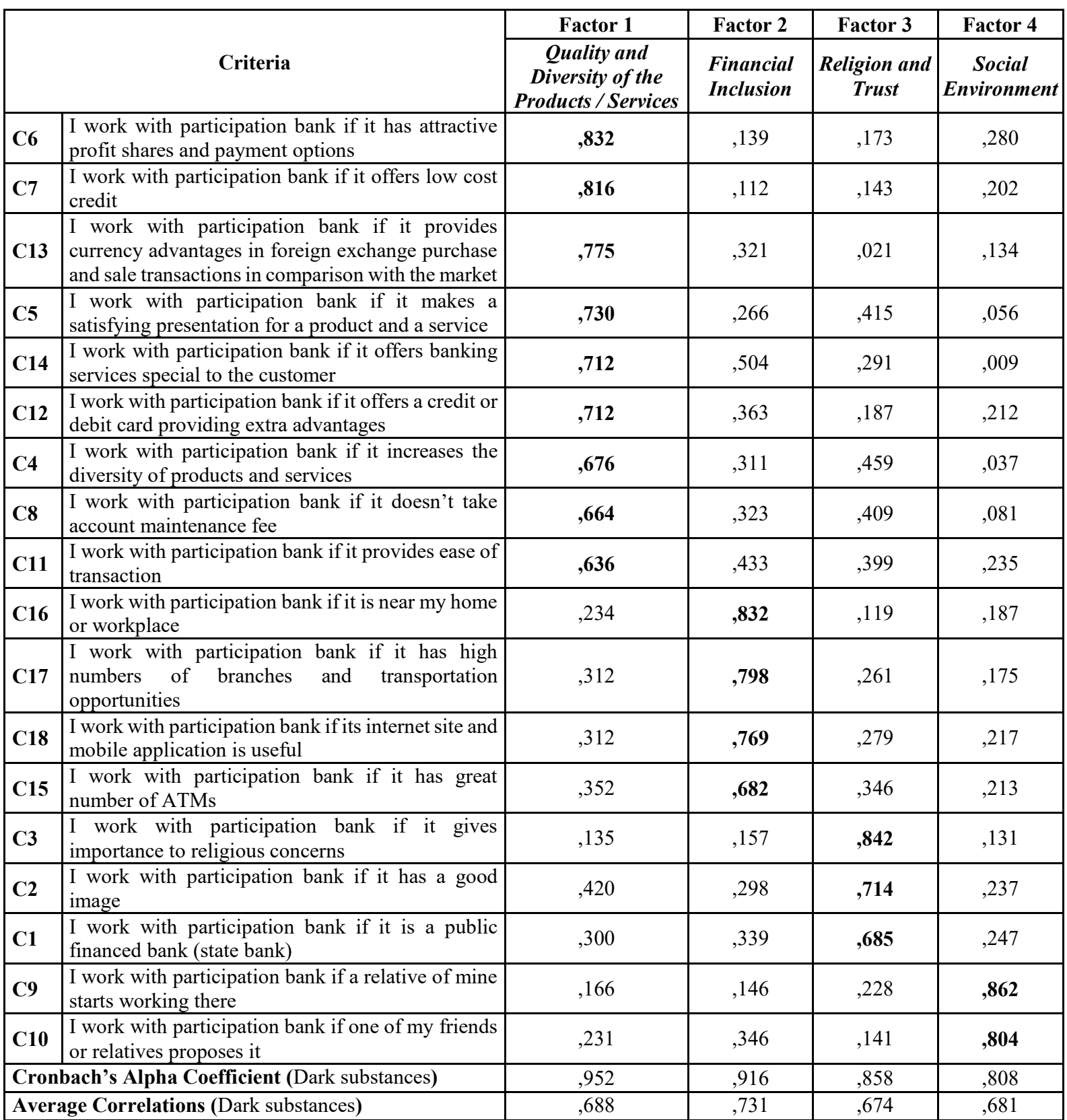

The rotated component matrix has been seen in Table 5. This matrix has given the final outcome of factor analysis related to the factors affecting the decision of usage participation banking in future. Under which factor a variable will be placed has been determined according to the factor loading it has. Generally, the loadings 0,50 or above have been accepted as really good (Kalayc1, 2010: 330). The criteria $4,5,6,7,8,11,12,13$ and 14 have the biggest loading under factor $1,15,16,17$ and 18 under factor 2, 1, 2 and 3 under factor 3,9 and 10 under factor 4 . When the factors have been named, factor 1 is "quality and diversity of the products and services", factor 2 is "financial inclusion", factor 3 is "religion and trust" and factor 4 is "social environment". Cronbach's alpha coefficient and average correlations have been calculated in order to determine whether every factor is reliable or not. It has been seen that cronbach's alpha coefficient and average correlation value of all factors are high. This situation has shown that every factor is reliable enough.

When all factors have been evaluated, the factor of "quality and diversity of the products and services" is the most important factor which is effective in the academicians' decisions of using participation banks because it is the highest one explaining the total variance $(30,818 \%)$. This factor has been followed by the "financial inclusion" factor explaining $20,756 \%$ of the total variance. "Religion 
and trust" factor has been the third most effective factor in decision of using participation banks in future explaining $16,225 \%$ of the total variance. The least effective factor affecting the preference for participation banks in future is "social environment" factor explaining $10,730 \%$ of the total variance.

\section{CONCLUSION}

A part of individuals in Turkey and the world abstain from interest income because of religious concerns. Therefore, there are idle resources which are not directed to conventional banks. This situation results in financial loss for both savers and economies where their savings are. Participation banks have aimed to help savers who have interest sensibility to keep their funds in safe and evaluate them. Participation banks has come to the forefront as a banking model realizing all kinds of banking activities in terms of interest free principle.

There are various factors affecting the preference of using participation banks in financial transactions. The aim of this study is to reveal the factors affecting the academicians' decisions of using participation banks in their financial transactions by giving up conventional banks. Within this scope, descriptive analyses have been used first and then factor analyses have been carried out.

According to the descriptive analyses, $13,4 \%$ of the academicians have been using participation banks. When the demographic qualifications of the academicians using participation banks have been examined, academicians who are male, married, aged between 31-40, professor doctors, have high income and know the difference between conventional and participation banks use participation banks more in comparison with others.

According to the results of factor analyses, the most important factor affecting the academicians' decisions of using participation banks by giving up conventional banks is "quality and diversity of the products and services". This shows that participation banks should give more importance to quality and diversity of the products and services in order to gain more customers. The best way to compete against conventional banks for participation banks is to increase the quality and diversity of the products and services. This result has shown similarities with the studies of Özsoy et al. (2013), Polat et al. (2014), Yildırım and Çakar (2016) in literature. The second most important factor affecting the academicians' decisions of using participation banks by giving up conventional banks is "financial inclusion". Similarly, Öndeş et al. (2018) has shown that insufficient numbers of branches and ATMs is the reason why participation banks are not preferred. In this connection, if participation banks increase their accessibility, they will have an increasing customer potential. The third most important factor affecting the academicians' decisions of using participation banks by giving up conventional banks is "religious and trust". Anaç and Kaya (2017), Demirdöğen and Özkul (2018), Çambel (2019), Dayı (2019), Erdoğan et al. (2020), have also reveal that religious factors are significant in decisions of using participation banks. Giving importance to religious values and having a reliable image are really important in terms of gaining new customers. The least important factor affecting the academicians' decisions of using participation banks by giving up conventional banks is "social environment". In literature, Özsoy et al. (2013) has showed that individual's social environment is effective in using participation banks in financial transactions.

Consequently, the quality and diversity of products and services, financial inclusion, religious and trust, social environment factors are effective. The most effective one is quality and diversity of products and services. Therefore, participation bank systems as an alternative to conventional banking systems can increase their customer potential with new products and increasing service quality. This has shown that participation banks should give more importance to financial technologies and comply with their improvements .In today's world, digital transformation has gained speed. Financial technologies have been arisen by combining technology and innovative business models. Conventional banks can easily adapt to these improvements. In conventional banks, innovation can be swiftly done but by participation banks, developing new products and services are much harder because of Islamic rules. In addition to this, financial technologies represent a new growth wave in Islamic finance industry. Especially, it should not be forgotten that improvements in blockchain applications have led to significant developments in the field of sukuk.

In accordance with the obtained results, several suggestions can be made for following studies. When the empirical studies carried out on indicatives of preference for participation banking in Turkey 
have been examined, it has seen that studies have been generally made on current customers and the number of studies focusing on potential customers who do not prefer participation banks is poor. So, it has been thought that this study will make important contributions to the literature. Carrying out large scale studies instead of local ones and focusing on potential customers make it possible to obtain more comprehensive results. This study has shown cross sectional qualification since the data has been gathered from a sample only once. The findings obtained in the study are meaningful and compatible with the results in literature. There is a need for longitudinal studies, which gather the data from a sample at least twice, in order to make thoroughly evaluations.

\section{REFERENCES}

Albayrak, A. and Özsoy, Ş. (2019). "Katılım bankacılığı ekosistemi: Paydaşlar, kurumlar ve piyasalar", Ş. Görmüş, A. Albayrak ve A. Yabanlı (Ed.), Katılım bankactlı̆̆ ekosistemi: Paydaşlar, kurumlar ve piyasalar içinde (78-99), İstanbul: TKBB Yayınları.

Anaç, T. and Kaya, F. (2017). "Katılım bankacılığı sektöründe bireysel müşterilerin banka tercih nedenleri üzerine bir araştırma: İstanbul örneği”, Ekonomik ve Sosyal Araştırmalar Dergisi, 13(2), 75-96.

Atici, G. (2018). "Islamic (participation) banking and economic growth: Empirical focus on Turkey", Asian Economic and Financial Review, 8(11), 1354-1364.

Çambel, H. (2019). İşletmelerin katılım bankası tercihini etkileyen faktörler: Bolu örneği. Yüksek Lisans Tezi, Bolu Abant İzzet Baysal Üniversitesi Sosyal Bilimler Enstitüsü, Bolu.

Dayı, F. (2019). "Katılım bankacılığının tercih nedenlerinin sadakat ve güven üzerindeki etkisi: Türkiye örneği”, Üçüncü Sektör Sosyal Ekonomi Dergisi, 54(4), 1788-1806.

Demirdogen, Y. and Kaplan, F. (2020). "The relationship between participation funds and macroeconomic variables: SVAR analysis approach", Turkish Journal Islamic Economics, 7(2), $37-53$.

Demirdöğen, Y. and Özkul, G. (2018). "Bankacılık işlemlerinde katılım bankaları tercihini etkileyen faktörler: Isparta örneği”, S. Bozkuş Kahyaoğlu ve Z.U. Özkara (Ed.), Katılım Finans: Teorik ve Ampirik Çalışmalar içinde (339-364), Ankara: Gazi Kitabevi.

Erdoğan, S., Gedikli, A., Yıldırım, S., Yıldırım, D., Yılmaz Genç, S., Haykır Hobikoğlu, E. and Erdoğan, F. (2020). "An investigation of participation banking performance in Turkey from costumer perspective: The case of Kocaeli province", Bilimname, 2020(41), 1095-1127.

Ergeç, E. H., Kaytancı, B. G. and Toprak, M. (2014). "Katılım bankası müşterilerinin bankacılık sistemi kullanım tercihleri: Mevduat bankaları için İslami bankacılık penceresi", Tüketici ve Tüketim Araştırmaları Dergisi, 6(2), 53-90.

Gençtürk, M. and Çobankaya, F. T. (2015). "Katılım bankalarının Batı Akdeniz bölgesindeki farkındalık düzeyinin tespiti”, Bankacılar Dergisi, 26(93), 82-105.

Gökçen, G. and Gönen, İ. (2017). "Katılım bankalarının finans sektörü içindeki yeri ve katılım bankalarına yönelik müşteri algısı", Finans Ekonomi ve Sosyal Araştırmalar Dergisi, 2(1), 6177.

Hazıroğlu, T. (2019). "Katılım felsefesi ve insani bankacılık", Ş. Görmüş, A. Albayrak ve A. Yabanlı (Ed.), Yaşayan ve gelişen katılım bankacılığ içinde (22-37), İstanbul: TKBB Yayınları.

https://iibf.sdu.edu.tr/tr/genel-bilgiler/tarihce-1693s.html, (02.05.2019).

IFDI. (2019). "Islamic finance development report: Shifting Dynamics", The Islamic Corporation for the Development of the Private Sector and Refinitiv, Access address: https://icdps.org/uploads/files/IFDI\%202019\%20DEF\%20digital1574605094_7214.pdf, (10.07.2020).

Kalaycı, İ. (2013). “Katılım bankacılığı: Mali kesimde nasıl bir seçenek?”, Uluslararası Yönetim İktisat ve İsletme Dergisi, 9(19), 51-74.

Kalaycı, Ş. (2010). SPSS uygulamalı çok değiş̧kenli istatistik teknikleri, Ankara: Asil Yayın Dağıtım. 
Indicators of Preference for Pariicipation Banking: A Research on People Who Do Not Use Participation Banking In Their Financial Transactions

Öndeş, T., Şimşek, A. and Sumer, S. (2018). "Katılım bankalarının kredi kullananlar açısından tercih edilmeme sebepleri: Atatürk Üniversitesi akademisyenleri üzerine bir uygulama", Atatürk Üniversitesi İktisadi ve İdari Bilimler Dergisi, 32(4), 897-920.

Özsoy, İ., Görmez, B. and Mekik, S. (2013). "Türkiye'de katılım bankalarının tercih edilme sebepleri: Ampirik bir tetkik”, Yönetim ve Ekonomi: Celal Bayar Üniversitesi İktisadi ve İdari Bilimler Fakültesi Dergisi, 20(1), 187-206.

Pehlivan, P. (2016). “Türkiye'de katılım bankacılığı ve bankacılık sektöründeki önemi”, Selçuk Üniversitesi İktisadi ve İdari Bilimler Fakültesi Sosyal Ekonomik Araştırmalar Dergisi, 16(31), 296-324.

Polat, A., Yesilyaprak, M. and Kaya, R. (2014). "Understanding Islamic bank selection of customers: A field research from Turkish participation banks", International Journal of Financial Research, 5(4), 22-38.

Salant, P. and Dillman, D. A. (1994). How to conduct your own survey, New York: John Wiley and Sons.

TKBB, (2020a). "Katılım bankacılı̆̆ı nedir? Nasıl çalışır?", Access address: https://www.tkbb.org.tr/Documents/Yonetmelikler/TKBB-Katilim-Bankaciligi-NedirBrosur.pdf, (10.05.2020).

TKBB, (2020b). "Katılım bankaları 2019", Access address: https://www.tkbb.org.tr/Documents/Yonetmelikler/Katilim-Bankalari-2019.pdf, (10.07.2020).

Toraman, C., Ata, H. A. and Buğan, M. F. (2015). "İslami bankacılık faaliyetlerine yönelik müşteri algısı üzerine bir araştırma”, Gaziantep University Journal of Social Sciences, 14(4), 761-779.

Törenek, M. and Yavuz, S. (2018). "Katılım bankacılığı tercihinin, müşterilerin bazı demografik özellikleri açısından incelenmesi”, Kafkas Üniversitesi İktisadi ve İdari Bilimler Fakültesi Dergisi, 9(18), 453-472.

Turan, Y. and Demirci, İ. (2019). "Akademisyenlerin faiz ve faizsiz finans kullanımına yönelik tutumları", Bilimname, 2019(39), 247-283.

Yanık, R. and Sumer, S. (2017). "Kamu katılım bankacılığının bankacılık sektörüne beklenen etkileri”, Turkish Studies, 12(31), 427-448.

Yanık, R. and Sumer, S. (2019). "Akademisyenlerin İslami bankac1lık algısı”, Atatürk Üniversitesi Sosyal Bilimler Enstitüsü Dergisi, 23(3), 1177-1190.

Y1ldırım, I. and Çakar, R. (2016). "A study on the factors influencing the preference of Islamic banking”, PressAcademia Procedia, 2(1), 552-563. 